\begin{tabular}{lll} 
ISS: 2356-4547 (Print), 2721-0006 (Online) & $\begin{array}{l}\text { Article History: } \\
\text { Submitted }\end{array}$ \\
Vol. 8, No. 1, Oktober 2021, (131-153), https://s.id/Man_Raf & Reviewed & $: 29 / 06 / 2021$ \\
Published By: Sekolah Tinggi Teologi Arastamar Bengkulu & Accepted & $: 01 / 09 / 2021$ \\
\hline
\end{tabular}

\title{
TAFSIR EFESUS 6: 5-8 TENTANG TEOLOGI KERJA DAN APLIKASINYA BAGI PEMUDA GEREJA
}

\author{
Hasahatan Hutahaean $^{1}{ }^{*}$, Nurliani Siregar ${ }^{2}$, Desmiyanti Tampubolon ${ }^{3}$ \\ Sekolah Tinggi Teologi Sumatera Utara ${ }^{13}$, Universitas HKBP Nommensen ${ }^{2}$ \\ *)Email Correspondance: hasea2014@gmail.com
}

Abstract: $\quad$ This article was written to describe the theological understanding of work among church youth and motivate youth to work according to God's word from Ephesians 6:5-8. This article aims to provide an understanding of what the purpose of human work is, provide an understanding of the Biblical concept of work, deepen the knowledge and understanding of congregation members about work theology according to Ephesians 6:5-8 with integrity and a good work ethic, provide an understanding of the contribution of Ephesians 6:5-8 in the relationship between workers and employers. The researcher uses a literature study and interprets the text with the method of theological interpretation. In addition, the author also distributed a questionnaire among church youth who had worked, to obtain a picture of their understanding of work theology. From the results of the questionnaire distributed, it was found that $42.22 \%$ of youth really understand work theology, and 52.77\%, understand work theology, but in its application, only $37.22 \%$ always do the correct life application. So, the researcher conducted deep interviews with several respondents and found that the youth of the HKBP Tanjung Sari church were still lacking in understanding the theology of work. And then they had to be afraid and trembled like Christ and had to be honest and have integrity at work places as a service to God.

Keywords: $\quad$ work ethic, work theology, integrity, good attitude, work-master relations

Abstraksi: Artikel ini ditulis untuk menggambarkan pemahaman teologis tentang bekerja di kalangan pemuda gereja dan memotivasi kaum muda untuk bekerja sesuai dengan firman Tuhan berdasar Efesus 6:5-8. Artikel ini bertujuan Pertama, untuk memberikan pemahaman tentang apa tujuan dari pekerjaan yang dilakukan manusia, dengan memberikan pemahaman tentang konsep kerja yang Alkitabiah. Kedua, memperdalam pengetahuan dan pemahaman anggota jemaat tentang teologi kerja menurut Efesus 6:5-8 dengan integritas dan sikap yang baik, etos kerja. Setelah itu secara bersaamaan memberikan pemahaman tentang hubungan antara pekerja dan majikan dari Surat Efesus 6:5-8. Peneliti menggunakan studi kepustakaan dan menafsirkan teks dengan metode tafsir teologis. Selain itu, penulis juga menyebarkan kuesioner di kalangan pemuda gereja yang pernah bekerja, untuk memperoleh gambaran pemahaman serta aplikasi mereka tentang teologi kerja. Dari hasil kuisioner yang disebar, diketahui bahwa 42,22\% kaum muda sangat memahami teologi kerja, dan 52,77\% memahami teologi kerja, namun dalam penerapannya hanya 37,22\% yang selalu melakukan penerapan kehidupan dengan benar. Maka peneliti melakukan wawancara lebih mendalam dengan beberapa responden dan menemukan bahwa pemuda gereja HKBP Tanjung Sari masih kurang memahami teologi kerja. Dan kemudian mereka harus takut dan gemetar seperti Kristus dan harus jujur dan memiliki integritas di tempat kerja sebagai pelayanan kepada Tuhan

Kata kunci: Etika Kerja, Teologi kerja, integritas, sikap yang baik, hubungan pekerja dan majikan 


\section{PENDAHULUAN}

Kerja adalah suatu usaha yang dilakukan seseorang baik sendiri atau bersama orang lain, untuk memproduksi suatu komoditi atau memberikan jasa. Kerja adalah mengeluarkan energi dalam melayani sesama yang memberi manfaat bagi pekerja, bermanfaat bagi komunitas dan memuliakan Allah (1Ptr. 2: 12). ${ }^{1}$ Natur manusia adalah bekerja dan dengan bekerja seseorang mendapatkan hasil atau imbalan. Tetapi banyak orang bekerja hanya untuk mendapatkan imbalan tanpa berfokus untuk menghasilkan karya terbaik yang dapat dinikmati banyak orang dan semakin hari telah kehilangan makna bekerja. ${ }^{2}$ Hal tersebut telah diteliti oleh Abdul Rohmat pengajar filsafat dari Universita Gajah Mada (UGM) ketika meneliti adanya potensi kapitalisme Barat di Indonesia, bahwa trend pekerja berorientasi kepada tugas semata daripada fungsi dari tenaga kerja yang lebih luas, hal ini terus bergerak menuju nir pekerja dengan maraknya penggunaan robot menggantikan tenaga manusia. ${ }^{3}$

Kitab Kejadian menunjukkan bahwa Allah adalah pekerja yang pertama dan yang terbaik di tengah-tengah dunia. ${ }^{4}$ Kitab Kejadian menyatakan penciptaan yang dilakukan Allah merupakan sebuah tindakan bekerja yang berlangsung selama 7 hari. Pada Kejadian 2: 15, Allah menempatkan manusia dalam taman untuk "mengusahakan dan memelihara" yang berarti bahwa Allah bekerja

\footnotetext{
${ }^{1}$ Robert Banks dan R. Paul Stevens, ed., The Complete Book of Everyday Christianity, Revised (Singapore: Graceworks, 2011), 1138.

2 Cuan Lie Seng, Calling at Work, Rahasia Bekerja dengan Totalitas (Bandung: PT.Visi Anugerah Indonesia, 2015), 21.

3 Abdul Rokhmat Sairah Z, "ETOS KERJA MANUSIA BUGIS-MAKASSAR SEBAGAI KRITIK TERHADAP KONSEP KERJA DALAM BUDAYA KAPITALISME BARU (Studi Filosofis Atas Persoalan Pengangguran di Indonesia)," Jurnal Filsafat 21, no. 1 (2011): 59, https://doi.org/10.22146/jf.4745.

${ }^{4}$ R.Paul Stevens, The Other Six Days: Vocation, Work and Ministry in Biblical Perspective (UK: Patermoster Publishing, 2000), 9.
} 
memelihara, namun juga manusia bekerja bagi Allah. ${ }^{5}$ Di satu sisi kekristenan mengimani bahwa Allah adalah Sang Pekerja Agung, bekerja dengan spektrum kerja yang luas yakni merancang, mencipta dan memelihara. Manusia diciptakan Allah menjadi mitra kerja-Nya untuk berkarya mengelola bumi dan seluruh ciptaan. ${ }^{6}$ Melalui pekerjaan, manusia menyatakan kasih Allah, keadilan Allah, kebenaran Allah. Sebab manusia yang diciptakan Allah memiliki kemampuan berpikir dan tanggung jawab, karena itu bekerja tidak bisa dipisahkan dari kehidupan manusia. ${ }^{7}$

Manusia adalah mahluk yang diciptakan segambar dengan Allah, sehingga manusia mewarisi karakteristik Allah, pribadi yang kreatif dan diberi mandat untuk bekerja (Kej 2: 15). ${ }^{8}$ Allah meminta manusia untuk melanjutkan kreasi Allah (creatio continua) dengan mengelolah seluruh ciptaan-Nya, oleh karena Tuhan, untuk Tuhan dan demi kemuliaan-Nya. Sebagaimana dinyatakan Heri Lim bahwa sejak penciptaan teks Alkitab menunjukkan pentingnya natur hubungan antara manusia dengan Allah penciptanya melalui segmen-segmen dalam hidupnya. ${ }^{9}$ Bekerja adalah bagian hidup pengikut Kristus, Menurut Andrew Abdi Tuhan meminta jemaat gereja untuk berfungsi sebagai garam dan terang dunia, supaya Tuhan memakai untuk menggarami lingkungan kerja masing-masing. ${ }^{10}$

5 Timothy Keller dan Katherine Learly Alsdorf, Apakah Pekerjaan Anda Bagian dari Pekerjaan Allah: Mengaitkan Karya Anda Dengan Karya Allah, ed. oleh Sutrisna Harijanto (Surabaya: Perkantas Jawa Timur, 2014), 31, 33.

6 Jansen dan Eben Ezer Siadari Sinamo, Teologi Kerja Modern dan Etos Kerja Kristiani (Jakarta: Institut Darma Mahardika 2011, 2013), 14-15.

7 Sabaria Zega, "Pentingnya Memahami Entrepreneurship Secara Biblikal bagi Hamba Tuhan," KHARISMATA: Jurnal Teologi Pantekosta 1, no. 2 (2019): 120, https://doi.org/10.47167/kharis.v1i2.16.

8 Paul Gunadi dan dkk., ed., Memaksimalkan Karier Anda: Kumpulan Artikel Tentang Menemukan dan Mengembangkan Karier (Bandung: PT. Visi Anugerah Indonesia, 2014), 27.

9 Heri Lim, "Memahami Kisah Penciptaan Manusia Dan Alam Semesta: Sebuah Pendekatan LitererTerhadap Kejadian1-2," Amanat Agung 14, no. 2 (2018): 200, https://doi.org/10.47754/jaa.v14i2.355.

10 Gunadi dan dkk., Memaksimalkan Karier Anda: Kumpulan Artikel Tentang Menemukan dan Mengembangkan Karier, 75. 
Hal tersebut menunjukkan orang percaya memiliki semangat kerja yang tinggi, berintegritas, jujur dan disiplin. Terkait hal tersebut Kurniadi menuliskan bahwa Kristus yang ada di dalam diri seseorang akan mengubah cara hidup ${ }^{11}$, sehingga mampu memberi kepuasan kepada banyak orang, misalnya di dunia kerja. Sebab setiap pekerjaan adalah "pekerjaan Allah" yang memiliki nilai hakiki, sebab bekerja adalah dimandatkan oleh Allah, merupakan bagian dari panggilan Allah (Kej. 1: 28), juga bekerja itu harus disesuaikan dengan rencana Allah yang berarti memiliki relasi dengan Allah.

Dalam penelitiannya Dachi dan Lase mengungkap bahwa unsur spiritualitas serta budaya mengambil peran dalam membentuk etos kerja seseorang. ${ }^{12}$ Rendahnya etos kerja terkait dengan spiritualitas, Injil diyakini dapat memberi perubahan pada tata nilai seseorang dalam hidupnya termasuk menilai kerja, hubungan sosial dan pendidikan. Terkait hal tersebut Setiawan menuliskan bahwa Injil membawa dampak kepada kehidupan sosial termasuk taraf hidup dan ekonomi, bukan hanya perubahan spiritual. ${ }^{13}$ Stevan dan Ung berpendapat bahwa Allah membentuk, mencetak dan memperbarui seseorang saat bekerja sebab hal ini membawanya pada persekutuan dengan Allah. ${ }^{14}$ Wicaksana meneliti etos kerja kaum milenial pada satu perusahaan yang menunjukkan produktivitas satu

\footnotetext{
11 Trisno Kurniadi, "Penguasaan Diri Hamba Tuhan Dalam Pelayanan Kajian Eksegetikal 2 Timotius 4:1-8," Manna Rafflesia 3, no. 2 (2017): 133-134, https://doi.org/10.38091/man_raf.v3i2.72.

12 Otoriteit Dachi dan Delipiter Lase, "Etos Kerja Pendeta BNKP," SUNDERMANN: Jurnal IImiah Teologi, Pendidikan, Sains, Humaniora dan Kebudayaan 13, no. 1 (2020): 52, https://doi.org/10.36588/sundermann.v13i1.34.

13 David Eko Setiawan, "Dampak Injil Bagi Transformasi Spiritual Dan Sosial," BIA': Jurnal Teologi dan Pendidikan Kristen Kontekstual 2, no. 1 (2019): 89, https://doi.org/10.34307/b.v2i1.78.

14 R.Paul Stevens dan Alvin Ung, Taking Your Soul to Work, Mengatasi Sembilan Dosa Maut di Tempat Kerja (Jakarta: Literatur Perkantas, 2014), 211.
} 
perusahaan rendah karena etos kerja rendah. ${ }^{15}$ Etos kerja pemuda ini dapat diduga menjadi gambaran spiritualitas pemuda. Selanjutnya Uygur meneliti pada pengusaha muda di Turki bahwa spiritualitas yang segar, terbaharui pada kalangan pemuda memberikan daya juang yang kian tinggi. Daya juang itu terbukti dan bermanfaat untuk mempertahankan aktivitas wirausaha. ${ }^{16}$ Gambaran etos kerja ini memiliki kaitan dengan situasi pemuda-pemudi di Huria Kristen Batak Protestan (HKBP) Tanjungsari, Medan dengan fokus pada kalangan pemuda (bhs. Batak Naposobulung) khususnya pemuda-pemudi yang telah masuk pada dunia kerja. Jumlah pemuda yang bekerja sebanyak 118 orang (76 pria dan 42 wanita). Jumlah pemuda yang bekerja di perusahaan swasta sebanyak 86 orang, bekerja sebagai Pegawai Negeri Sipil/BUMN sebanyak 12 orang dan bekerja sebagai wiraswasta sebanyak 20 orang. ${ }^{17}$ Observasi tersebut menunjukkan masih adanya kesenjangan pemahaman dan implementasi etos kerja.

Kajian menunjukkan bahwa unsur pemahaman kerja dari sudut agama memiliki kontribusi terhadap kinerja dan etos kerja Pemuda. Generasi muda sebagai kelompok usia yang memiliki semangat, mempunyai keinginan yang terus ingin berkembang di tengah lapangan kerja yang ada. Sullivan memberikan usulan yang patut dicatat yakni agar para pekerja memiliki kecintaan pada pekerjaanya, sama seperti kasih agape yang diajarkan Allah kepada murid-murid

15 Seta A Wicaksana, Rosi Nurika, dan Aisyah Pia Asrunputri, "Gambaran Etos Kerja Pada Karyawan Generasi Milenial di PT X," ISOQUANT: Jurnal Ekonomi, Manajemen dan Akuntansi 4, no. 2 (2020): 195, https://doi.org/10.24269/iso.v4i2.457.

${ }^{16}$ Selçuk Uygur dkk., "Work Ethic, Religion and Moral Energy: the Case of Turkish SME OwnerManagers," International Journal of Human Resource Management 28, no. 8 (2017): 1227-1229, https://doi.org/10.1080/09585192.2016.1166790.

17 Parhalado Sekretaris Huria, "Buku Data Base Jemaat HKBP Tanjung Sari" (Medan, 2018). 
dalam Injil Yohanes. ${ }^{18}$ Pemahaman teologi tentang kasih khususnya agape sangat dibutuhkan di dunia kerja, yakni mengasihi pekerjaan, bekerja dengan kasih, menjunjung tinggi kasih terhadap Allah dengan mangasihi pekerjaan menjadi faktor penting untuk mewujudkan etos kerja pemuda Kristen. Dengan demikian ada keterkaitan pemahaman teologi kerja, terhadap etos kerja seseorang. Penelitian ini menunjukkan urgensi tersebut dengan melakukan tafsir terhadap surat Efesus dan aplikasinya bagi pemuda.

\section{METODE}

Penelitian ini menerapkan pendekatan kualitatif, yaitu konsentrasi menemukan makna, pengertian atau konsep, karakteristik, serta gejala yang ada sebagai bagian fenomena alami dan holistik, mengutamakan kualitas, yang menghasilkan data deskriptif. ${ }^{19}$ Penelitian ini melakukan survey lapangan (field research) dengan menyebarkan angket kepada naposobulung gereja HKBP Tanjung Sari, Medan untuk mengetahui pemahaman responden tentang teologia kerja dan aplikasinya dalam pekerjaan. Daftar pertanyaan dapat bersifat terbuka, yaitu jawaban tidak ditentukan sebelumnya oleh peneliti, dan dapat bersifat tertutup yaitu alternatif pertanyaan telah ditentukan sebelumnya oleh peneliti, berupa pilihan dengan cara memberi tanda pada kolom yang disediakan. ${ }^{20}$ Menggunakan pertanyaan tertutup akan membantu responden menjawab lebih cepat dan memudahkan peneliti untuk melakukan analisis data dari seluruh angket yang terkumpul. Menurut Hamzah tahapan awal dari penelitian ini perlunya

\footnotetext{
18 Sandra Sullivan-Dunbar, Human Dependency and Christian Ethics, Human Dependency and Christian Ethics (London: Cambridge University Press, 2017), 114-116, https://doi.org/10.1017/9781316717677.

${ }^{19}$ Amir Hamzah, Metode Penelitian Kualitatif (Malang: Literasi Nusantara, 2019), 35.

20 Juliansyah Noor, Metodologi Penelitian: Skripsi, Tesis, Disertasi, dan Karya IImiah (Jakarta: Kencana Prenada Media Group, 2011), 139.
} 
pengumpulan data dengan wawancara kepada responden. ${ }^{21}$ Dalam hal ini peneliti menggunakan pertanyaan tertutup. Sedangkan terhadap teks Alkitab dilakukan penafsiran lebih bersifat teologis. ${ }^{22}$

\section{HASIL}

Hasil survey terhadap responden di HKBP Tanjung Sari, Medan, khususnya kaum Pemuda diperoleh data dan analisis peneliti adalah sebagai berikut; pertama dari sisi pemahaman responden terhadap teologi kerja di bawah 50\%. Bahkan pemahaman tentang kerja dengan setulus hati hanya 53\%. Fakta ini menunjukkan rendahnya pemahaman pada segmen pekerja muda jemaat gereja pada sampel. Dalam penghayatan, responden yang taat dan takut kepada atasan bahkan tidak lebih dari 10\%. Hal ini menandakan krisis attitude dalam diri seorang pekerja kepada atasannya. Untuk penghayatan rasa bekerja itu seperti bekerja kepada Tuhan hanya 50\%. Tentu persentase ini mengkuatirkan bagi dunia kerja dari angkatan kerja beragama Kristen. Sedangkan hal ini di bagian aplikasi hanya dilakukan oleh $40 \%$ responden. Gambaran data ini menunjukkan pemahaman, penghayatan dan aplikasi terhadap teologi kerja sangat rendah. Hasil penelitian ini adalah pemahaman tentang konsepsi teologi kerja berdasarkan tafsiran efesus 6:5-8, yang memiliki latar belakang sosial seorang budak, pekerja adalah seorang hamba yang melayani, sikap hamba kepada tua dan ciri-ciri hamba kristus dan konsep Alkitabiah teologi kerja.

${ }^{21}$ Amir Hamzah, Metode Penelitian Fenomenologi (Malang: Literasi Nusantara, 2020), 98.

22 Hasahatan Hutahaean, "Mengenal Ciri Tafsiran Ajaran Sesat," Didaskein 1, no. 1 (2013): 59, https://doi.org/ISSN 2338-2503. 


\section{PEMBAHASAN}

Paulus Wahana menuliskan bekerja adalah salah satu wujud untuk mencapai kebahagiaan. Selain hal ini, kerja juga dapat mendatangkan rasa damai bagi seseorang, menikmati ketenangan serta rasa kepuasan dan kebahagiaan diri seeorang (bonum delectabile). ${ }^{23}$ Secara kristiani kerja bermakna panggilan Tuhan dan anugerah kepada seseorang untuk kemuliaan Tuhan dan untuk kepuasan manusia, yang diilhami oleh Roh Kudus sebagai realitas ciptaan baru. Allah menemukan kesenangan dalam bekerja (Kej. 1: 31), seperti pekerjaan yang baik dan memuaskan, para pekerja juga harus melihat diri mereka dalam pekerjaan itu. ${ }^{24}$ Bekerja adalah suatu panggilan Ilahi yang menuntut pertanggungjawaban. Oleh karena itu seseorang tidak dianjurkan untuk meninggalkan pekerjaannya dan hidup membiara, melainkan agar sungguh-sungguh melayani sesama manusia dimana Allah menempatkan dalam suatu posisi. ${ }^{25}$ Melalui pekerjaan, betapapun rendahnya, orang lain beroleh pemeliharaan Allah, karena Allah menetapkan berbagai posisi dalam kehidupan dunia ini sebagai saluran kasih dan pemeliharaan-Nya untuk manusia.

\section{Konsepsi Teologi Kerja Berdasarkan Tafsiran Efesus 6:5-8}

Paulus menulis surat ini ketika sedang berada dalam penjara di Roma (Ef 3: 1; Ef 4: 1; Ef 6: 20) dan surat ini adalah surat edaran kepada jemaat secara umum. Secara eksplisit pada Efesus 1: 1 Paulus dan menyamakan diri dengan

23 Paulus Wahana, "Mengusahakan Kebahagiaan Dalam Kegiatan Kerja," Jurnal Filsafat 27, no. 2 (2018): 247, https://doi.org/10.22146/jf.32803.

${ }^{24}$ Keller dan Alsdorf, Apakah Pekerjaan Anda Bagian dari Pekerjaan Allah: Mengaitkan Karya Anda Dengan Karya Allah, 33.

25 Lilis Ermindyawati, "Konseling Kristen Terhadap Wanita Yang Mengalami Kecanduan Kerja," Evangelikal: Jurnal Teologi Injili dan Pembinaan Warga Jemaat 1 No.1 (2017): 71. 
murid Yesus yang lain. ${ }^{26}$ Maka sejak abad kedua hingga awal abad ke 18, surat Efesus diterima sebagai surat Paulus. Terkait hal tersebut Hasahatan menuliskan bahwa Paulus menggunakan konvensi-konvensi yang berlaku di zamannya. ${ }^{27}$ Paulus tinggal dan melayani di Efesus selama 3 tahun (Kis. 20: 31). Dalam Kisah Para Rasul 20: 17-38 Paulus mengadakan perpisahan pada jemaat Efesus. Paulus melayani dengan rendah hati, penuh cucuran air mata, mengalami banyak tantangan bahkan banyak ingin membunuhnya (Kis. 20: 19). ${ }^{28}$ Namun Paulus tetap memberi waktu untuk bersaksi kepada orang Yahudi dan Yunani agar bertobat dalam Kristus Yesus (Kis. 20: 21).

\section{Latar Belakang Sosial Seorang Budak}

Budak adalah hal yang legal pada masa itu, banyaknya budak dalam populasi penduduk, bukan karena mereka kaum terabaikan atau yang tidak berpendidikan, tetapi kadang ada kaum terpelajar menjadi budak karena kalah dalam peperangan. Budak hadir karena ketidakmampuan membayar hutang, keturunan orangtua seorang budak dan menikah dengan budak. Banyak budak yang memiliki talenta dan ketrampilan oleh tuannya dipekerjakan pada orang lain dan diberi upah. ${ }^{29}$ Tetapi pada umumnya, budak dianggap sebagai things (benda mati) yang menjadi milik tuannya dan tidak memiliki sosial kehidupan karena dimiliki penuh oleh tuannya. Pejanjian Lama dan Perjanjian Baru menyatakan

26 Yesri Esau Talan, Diselamatkan Oleh Anugerah: Sebuah Analisis Teologis Surat Efesus, ed. oleh Made Nopen Supriadi (Bengkulu: Permata Rafflesia, 2021), 19-21.

27 Hasahatan Hutahaean, "Pengantar Memahami Surat Roma Dengan Baca Gali Alkitab," Cultivation 1, no. 2 (2017): 7.

28 Tom Wright, Kisah Para Rasul Untuk Semua Orang I., ed. oleh Nancy Poyoh (Surabaya: Literatur Perkantas Jawa Timur, 2011), 190, 191, 196.

29 baca. Carlo Ginzburg, "Latitude, Slaves, and the Bible," dalam Science without Laws (Durham: Duke University Press, 2021), 243-63, https://doi.org/10.2307/j.ctv1220m9h.14. 
bahwa budak mempunyai kesempatan untuk beroleh pengampunan, dibebaskan menjadi orang merdeka dengan berbagai ketentuan yang berlaku. ${ }^{30}$

Hamilton menjelaskan topik "Budak dan Tuan" menjelaskan bahwa hampir semua pekerjaan dilakukan oleh budak, termasuk guru dan dokter, juga orang-orang yang bekerja di kekaisaran seperti sekretaris yang mengurus suratsurat dan keuangan juga seorang budak. Namun banyak tuan yang memperlakukan budaknya dengan baik dan menjalin sikap setia seorang budak pada tuannya. ${ }^{31}$ Jika budak melarikan diri, akan diberikan tanda $\mathrm{F}$ (fugitive: buronan) dan resikonya bisa dibunuh. Paulus memberi nasehat kepada Filemon untuk menerima Onesimus (Filemon 1: 16) budak yang telah melarikan diri, bukan hanya sebagai budak melainkan sebagai saudara. Dengan menunjukkan hal itu, Filemon mengangkat derajat Onesimus sebagai saudara dan bukan hanya sebagai hamba.

Perbudakan dalam masyarakat Ibrani lebih ringan daripada Yunani dan era Romawi lebih buruk lagi. Kekejian dosa perbudakan terletak pada perlakuan kepada budak sebagai benda milik kesayangan dan bukan sebagai manusia. Sementara pada awal lahirnya kekristenan, jumlah orang Kristen sedikit dan tidak berpengaruh dalam kerajaan Romawi. Agama Kristen belum diakui dan belum memiliki kuasa politik. Lahirnya kekristenan dan orang-orang yang menjadi percaya pada Kristus, belum bisa mengubahkan masyarakat dan menghapuskan

30 James A. Sanders, "Jubilee in the Bible," Biblical Theology Bulletin 50, no. 1 (2020): 5-6, https://doi.org/10.1177/0146107919892838.

${ }^{31}$ lan Hamilton, Ephesians: The Lectio Continua Expository Commentary on the New Testamen, ed. oleh Joel R Beeke dan Jon D Payne (Grand Rapids: Reformation Heritage Books, 2017), 231-238. 
perbudakan pada saat itu. ${ }^{32}$ Paulus hanya dapat membukakan pemikiran bagi jemaat seperti kepada Filemon untuk menerima Onesimus bukan hanya sebagai budak tapi sebagai saudara. Lagi pula di banyak kota, jumlah budak lebih besar dari jumlah tuan, sehingga jika perbudakan dihapus, maka masyarakat akan hancur, dan jika para tuan membebaskan semua budaknya, maka budak-budak itu akan menganggur dan tidak memiliki apa-apa. Benardo Cho menulis bahwa kebajikan yang menyangkut budak tidak normative, artinya tuan-tuan boleh melakukan apa saja sesukanya. ${ }^{33}$

\section{Pekerja Adalah Seorang Hamba Yang Melayani}

Doúloi (bentuk jamak) mempunyai kata dasar doulos yang berarti budak, hamba, pegawai raja, -orang yang bergantung pada, Para hamba diminta untuk taat kepada tuan-tuan mereka di dunia dan ketaatan mereka ada hubungannya dengan Ketaatan mereka kepada Kristus. ${ }^{34}$ Ebed (Ibrani) dapat berarti budak/hamba, hamba dari raja, pelayan Allah, melayani sebagai nabi Allah. Sehingga sebagai budak/hamba artinya melayani, sebagai sebuah kehormatan melayani seperti kepada Allah. Tuhan sendiri memanggil Musa sebagai pelayan$\mathrm{Nya}^{35}$ (Bil. 12: 7-8) yang mewujudkan firman Allah dan bekerja sebagai pelayan yang aktif, Musa taat kepada Allah dan dipilih untuk melayani-Nya.

Paulus berpandangan budak bertanggung jawab dan secara moral wajib menaati tuannya di dunia dan melakukannya dengan sikap taat kepada Kristus, sebagai hamba-hamba Kristus menjalankan pelayanan untuk Tuhan dan bukan

32 Ulrike Roth, "Paul, Philemon, and Onesimus: A Christian design for mastery," Zeitschrift fur die Neutestamentliche Wissenschaft und die Kunde der Alteren Kirche 105, no. 1 (2014): 107, https://doi.org/10.1515/znw-2014-0006.

33 Bernardo Cho, "Subverting Slavery: Philemon, Onesimus, and Paul's Gospel of Reconciliation," Evangelical Quarterly 86, no. 2 (2014): 102, https://doi.org/0014-3367.

${ }^{34}$ Band. Talan, Diselamatkan Oleh Anugerah: Sebuah Analisis Teologis Surat Efesus, 19.

${ }_{35}$ Mary W Clunie, The Bible and Slavery: A Brief Examination of the Old and New Testaments on Servitude (London: Forgotten Books, 2018), 12. 
untuk manusia. ${ }^{36}$ Kemudian Clunie menegaskan bahwa perspektif budak sudah berubah, mereka telah dibebaskan dari keharusan menghamba kepada manusia, menjadi bebas untuk melayani Kristus. ${ }^{37}$

\section{Sikap Hamba Kepada Tuan}

Menurut Lutgert seorang pekerjaan perlu memiliki sikap hormat. ${ }^{38}$ Kata takut adalah metafora hormat (lih.1Kor. 2: 3; 2Kor. 7: 15; Flp. 2: 12). Perasaan takut dan gentar sumbernya dari Allah (Kej. 9: 2, Kel. 15: 16, Ul. 2: 25). Ketaatan para budak bukan karena perlakuan majikan yang cenderung bertindak kasar dan jahat. Seorang pekerja juga perlu bekerja dengan tulus hati. Turner menyebut bahwa 'kepribadian' seseorang hendaknya elegant sebagai dampak relasinya dengan Kristus. ${ }^{39}$ Orang percaya menjalankan hidup mereka di setiap bidang seperti kepada Tuhan (lih. Kol. 3: 22-25 dan Rom. 14: 7-9), bukan dimotivasi oleh nilai atau manfaat dari orang lain. Harrill menekankan pentingnya kesehatian pekerja dengan tuannya sebagai ekspresi hubungan di dalam Kristus, hal tersebut dapat dipersamakan dengan 'tubuh kristus' di dunia kerja. ${ }^{40}$ Karena itu sikap berontak dalam diri pekerja Kristen hendaknya dipertimbangkan, lebih luas lagi, menurut Yoel Benyamin seorang karyawan dan tuan harusnya sama-sama taat kepada Tuhan. $^{41}$

36 Lynn H. Cohick, "EPHESIANS 6," dalam Ephesians: A New Covenant Commentary, 1st ed. (Cambridge UK: The Lutterworth Press, 2020), 147, https://doi.org/10.2307/j.ctt1cg4m17.11.

${ }^{37}$ Clunie, The Bible and Slavery: A Brief Examination of the Old and New Testaments on Servitude, 71.

38 Gerhard Kittel dan Gerhard Friedrich, ed., Theological Dictionary of the New Testament (Grand Rapids: Wm. B. Eerdmans Publishing Co., 1997), 189.

39 Baca. Max Turner, "Approaching 'personhood' in the New Testament, with special Reference to Ephesians," Evangelical Quarterly: An International Review of Bible and Theology 77, no. 3 (2021): 211-33, https://doi.org/10.1163/27725472-07703002.

40 J. Albert Harrill, "Ethnic Fluidity in Ephesians," New Testament Studies 60, no. 3 (2014): 398, https://doi.org/10.1017/S0028688514000046.

41 Yoel Benyamin, Keselamatan dan Kehhidupan Kristen; Studi Eksegesa Terhadap Kitab Efesus (Luwuk: Pustaka Star's Lub, 2020), 169. 
Ketaatan yang dituntut Paulus adalah ketaatan dengan tulus hati seperti kepada Tuhan. Apa yang dilakukan sama dengan yang ada dalam hati. Hal ini berarti bahwa tidak ada pemisahan antara kehidupan yang sakral dan sekuler, segala sesuatu adalah sakral (rohani) karena dilakukan sebagai bentuk ketaatan kepada Kristus. ${ }^{42}$ Sejalan dengan itu ketaatan kepada tuan bersifat inklusif (1Pet. 2: 18, Kol. 3: 22-25) sepanjang tidak bertentangan dengan ketaatan kepada Kristus. Pada bagian ini ada tuntunan tuan dan pekerja menjalin hubungan dalam kasih yang lebih benar. Hubungan pekerja dengan pemberi kerja akan lebih baik lagi jika mempunyai dasar kasih di dalam Tuhan. Grizzle mengulas hidup dalam kasih Allah untuk menciptakan nuansa surgawi dalam dunia yang sedang dijalani. ${ }^{43}$ Dengan demikian ada landasan yang akan mempererat hubungan kedua pihak, meski hak dan kewajiban tidak dapat diabaikan.

Saat ini perbudakan sudah dihapuskan dan menjadi illegal. Setiap pekerja dan pengusaha harus tunduk pada peraturan Undang-Undang tenaga kerja yang mengatur jam kerja, upah dan seluruh hak dan kewajiban pekerja. Undang-undang tersebut seperti (UU 13 2003,UU 1/1970 Kepres 22/1993 PP 14/1993, Permen 04/1993 \& Permen 01/1998). Dengan adanya undang-undang ini, pekerja dilindungi dan pengusaha juga memiliki tanggung jawab atas semua pekerjanya, sehingga tidak terjadi perlakuan yang tidak manusiawi kepada para pekerja.

\section{Ciri-ciri Hamba Kristus}

Pertama, melakukan pekerjaan dengan baik bukan hanya karena diawasi, bukan hanya dilakukan di depan mata majikan, yang hanya menyenangkan

\footnotetext{
42 Wirianto Ng, Gundari Ginting, dan Lukgimin Aziz, "Hubungan Pemahaman Pelayanan Dan Panggilan Dengan Kesetiaan Pengerja Di Gereja," Manna Rafflesia 7, no. 1 (2020): 165, https://doi.org/10.38091/man_raf.v7i1.134.

43 Trevor Grizzle, Ephesians, A Pentecostal Commentary, ed. oleh John Christopher Thomas, Ephesians (Leiden: Brill, 2019), 304, https://doi.org/10.1163/9789004397224.
} 
manusia (anthropareskos). Ketaatan seorang hamba sebagai hamba-hamba Kristus adalah dengan melakukan kehendak Allah, melakukannya sebagai sebuah pelayanan kepada Allah. $^{44}$ Kedua, melakukannya dengan segenap hati (ek psyches) secara hurufiah berarti-keluar dari jiwa, atau segenap jiwa, yang berarti ketaatan itu didorong oleh keinginan dari dalam untuk taat (ikhlas). Oleh ketaatan yang sesungguhnya kepada tuan seperti kepada Kristus. Ketiga, hamba harus menjadi hamba yang berhati nurani, kekristenannya harus membuat orang mampu bekerja lebih keras. Kekristenan tidak menawarkan seseorang untuk melarikan diri dari situasi yang sulit, sebaliknya memampukannya menghadapi situasi itu dengan lebih baik.

Bekerja untuk tuan disejajarkan dengan pelayanan kepada Kristus, tidak ada paksaan untuk melakukannya. Ketaatan hamba bukan untuk kepentingan tuan, tapi untuk Kristus. Meski budak bekerja bagi tuan atau majikan namun persembahan kemuliaan adalah untuk Kristus. Karena itu perspektif budak sudah berubah. Tugas yang biasa, sekarang berubah menjadi tugas yang luhur, yaitu melakukan kehendak Allah. Alister E. McGrath menyatakan bahwa pembaruan pemikiran Kristen menjadi penting untuk semua segmen kehidupan jika tidak maka kekristenan akan punah. ${ }^{45}$ Para budak sudah dibebaskan dari keharusan menghamba kepada manusia, menjadi bebas untuk melayani Kristus, sebagai hamba-hamba yang melayani Tuhan dan bukan manusia.

${ }^{44}$ Band. Benyamin, Keselamatan dan Kehhidupan Kristen; Studi Eksegesa Terhadap Kitab Efesus, 170. Christian mind," Evangelical Quarterly 83, no. 2 (2011): 134-135, https://doi.org/0014-3367. 


\section{Bekerja Secara Alkitabiah}

Kata bekerja yang digunakan dalam Kejadian 2: 15 adalah $l \partial-' \bar{a}-\underline{b} \partial-\underline{d} \bar{a} h$ (bekerja). Keller menjelaskan kata tersebut memiliki makna melayani, menjalankan, mengerjakan dalam perbudakan, mengikat, ditempa dan memuja. ${ }^{46}$ Kata yang sama digunakan dalam Perjanjian Lama untuk kata bekerja adalah: usaha/upaya, tugas, kerja keras, melayani. ${ }^{47}$ Bekerja adalah mandat Allah yang pertama bagi manusia, Ia menempatkan manusia itu dalam taman untuk mengelola taman itu (Kej. 2: 15) dan bukan sebagai kutukan atau hukuman atas dosa, karena perintah itu diberikan sebelum manusia jatuh dalam dosa. Priesteta menuliskan siapapun dengan status pekerja hendaknya turut dalam mewujudkan kesejahteraan masyarakat dengan bekerja secara maksimal karena bekerja adalah ibadah. ${ }^{48}$ Manusia bekerja karena Allah juga adalah Allah yang bekerja. Setiap hal yang dilakukan manusia berhubungan dengan Allah. Setiap kegiatan manusia ada kaitannya dengan Allah dan sepengetahuan Allah. Segala sesuatu dilakukan untuk Allah dan berkaitan dengan Allah.

Bagi masyarakat Yunani, bekerja adalah cara hidup yang menunjukkan martabat manusia, sedangkan bagi masyarakat Ibrani, bekerja adalah bagian perintah Tuhan untuk dilakukan dan tidak ada pengecualian, semua harus bekerja. Tuhan Yesus sendiri dikenal sebagai pekerja, seorang tukang kayu (Mrk. 6: 3). Kitab-kitab Injil lebih menekankan Tuhan Yesus dalam aktifitasnya sebagai pengkhotbah, penyembuh, melepaskan kuasa-kuasa gelap dan pekerjaanpekerjaan mujizat lainnya. Terkait hal tersebut Manurung menuliskan bahwa

\footnotetext{
46 Banks dan Stevens, The Complete Book of Everyday Christianity, 11.

47 Alan Richardson, The Biblical Doctrine of Work (London: SPCM Press, 1963), 11.

48 Astrid Cynthia Priesteta, "MENGINTEGRASIKAN PELAYANAN SOSIAL MELALUI PUSAT KESEJAHTERAAN SOSIAL (PUSKESOS) DI KELURAHAN DAGO KOTA BANDUNG," Pekerjaan Sosial 18, no. 1 (2019): 95, https://doi.org/10.31595/peksos.v18i1.158.
} 
keberadaan Yesus sebagai representasi kehadiran Allah mampu mengubah sikap pengikut-Nya termasuk dalam budaya kerja. ${ }^{49}$ Paulus dikenal sebagai tukang tenda (Kis. 18: 3) dan pekerja keras (1Kor. 4: 12; 2Kor. 11: 27). ${ }^{50}$ Dalam Kisah Para Rasul 20: 34-35, Paulus menunjukkan bahwa dengan bekerja dapat menjadi teladan. Dapat disandingkan dalam bagian ini bahwa kepuasan jemaat-jemaat terhadap Paulus seturut dengan kualitas diri sesuai dengan ajarannya. ${ }^{51}$

\section{Pemahaman Tentang Teologia Kerja}

Hasil di atas menggambarkan bahwa rata-rata secara persentase yang sangat memahami teologia kerja adalah $42,22 \%$ dan yang memahami teologia kerja 52,7\%. Bagi peneliti ini angka yang kecil dan memprihatinkan. Hal itu menggambarkan bahwa pemahaman dan penghayatan tentang teologia kerja cukup tinggi tetapi hal itu tidak terlihat cukup baik di aplikasi dalam bekerja. Untuk kebenarannya peneliti melakukan wawancara (deep interview). Dari hasil wawancara, peneliti mendapati bahwa pemuda gereja kurang dalam pemahaman tentang teologia kerja, kurang memahami bahwa bekerja dengan takut dan gentar kepada atasan harus dilakukan dengan sikap taat kepada Kristus, yang berarti setiap kali bekerja mereka harus menjaga integritas, taat kepada firman Tuhan. Pemuda juga kurang memahami bahwa bekerja adalah sebuah ibadah dan pelayanan kepada Tuhan yang membuat mereka dapat bekerja dengan tulus ikhlas, tetap bekerja dengan baik sekalipun tidak sedang diawasi oleh atasannya,

49 Frans Setyadi Manurung, "Teologi Keramahan Allah: Sebuah Pembacaan Kristologi Lukas," GEMA TEOLOGIKA: Jurnal Teologi Kontekstual dan Filsafat Keilahian 3, no. 2 (2018): 192.

50 Paulus membuat tenda dengan menjahit dari kulit kambing menjadi tenda yang dijual untuk penjual-penjual lokal, suatu ketrampilan yang mungkin dipelajarinya di Tarsus, termasuk latar pendidikannya. (Lih. Robinson Rimun, "Latar Belakang Hidup Dan Pendidikan Rabinik Paulus Dalam Kaitannya Dengan Perjumpaannya Dengan Kristus," PASCA: Jurnal Teologi Dan Pendidikan Agama Kristen 15, no. 2 (2019): 3 , https://doi.org/10.46494/psc.v15i2.60.)

51 Yonas Boky, "Analisis Tingkat Kepuasan Mahasiswa Terhadap Pelayanan Akademik Sekolah Tinggi Theologia Jaffray Makassar," Jurnal Jaffray 14, no. 2 (2016): 274, https://doi.org/10.25278/jj71.v14i2.213. 
karena ini adalah sebuah ketaatan kepada Kristus dan pada akhirnya akan mendapat penilaian dari Allah.

\section{Penghayatan Tentang Teologia Kerja}

Pemuda tidak menghayati teologia kerja, tampak dari persentase hanya $37,22 \%$. Dari wawancara peneliti dengan beberapa responden, didapati bahwa para pemuda gereja kurang bisa membedakan apa arti pemahaman dan penghayatan tentang teologia kerja. Pemuda sebatas memahami bahwa bekerja adalah untuk menyenangkan atasan dan tidak memahami bahwa bekerja adalah seperti melakukan pelayanan kepada Tuhan. Data angket tersebut memberikan gambaran penghayatan yang sangat kecil dan patut diperhatikan agar ada peningkatan. Dengan asumsi bahwa penghayatan yang baik akan menghasilkan aplikasi yang baik pula.

\section{Aplikasi Dalam Kerja}

Dalam aplikasinya diperoleh persentase yang sering melakukan prinsip teologia kerja adalah 43,33\%. Jumlah ini sangat kecil karena pemahaman akan mempengaruhi bagaimana seseorang bekerja. Hal ini menunjukkan bahwa ada saat-saat dimana pemuda gereja tidak bersikap jujur dan berintegritas, dan tidak melakukan pekerjaan dengan takut dan gentar. Menurut peneliti, lingkungan pekerjaan yang kompromi dengan ketidakbenaran juga menjadi salah satu pemicunya, sehingga mereka takut untuk hidup benar. Dalam konteks gereja HKBP hendaknya mampu memberi pengajaran terhadap generasi muda tentang 
bagaimana seharusnya seorang pekerja yakni kejujuran serta keadilan dapat dihidupi kalangan pemuda dalam dunia kerjanya. ${ }^{52}$

Dalam hidup setiap pekerja Kristen tidak ada pemisahan antara hidup yang sakral dan sekuler, semua hal dilakukan untuk menyenangkan hati Tuhan, menjadi sebuah pelayanan (ibadah) yang berkenan bagi Allah. Hati yang berpusat pada Allah, pasti akan selalu melakukan kehendak Allah. Ketaatan hamba kepada tuannya adalah sama seperti ketaatan kepada Kristus yang dilakukan dengan sikap takut dan gentar. ${ }^{53}$ Untuk meningkatkan persentase pemuda gereja supaya sangat memahami teologia kerja, diperlukan adanya pola pembinaan pemuda yang berkesinambungan dengan mempelajari bahan-bahan tentang teologia kerja. Tidak ketinggalan implikasi prinsip-prinsip teologia kerja juga diajarkan dalam kelompok-kelompok penelaahan Alkitab, maupun dalam kelompok-kelompok besar pertemuan pemuda di gereja yang mendorong pemuda hidup dalam prinsip etika yang benar, hidup jujur, berintegritas, bekerja dengan tulus iklas dan melakukannya seperti kepada Kristus. Akan menjadi lebih baik, jika pemahaman tentang teologia kerja juga menjadi salah satu topik dalam katekisasi remaja, sehingga sejak usia yang lebih muda, mereka sudah diberikan pemahaman teologia kerja dan memiliki sikap hidup jujur, integritas dan kompeten di dunia kerja nantinya. ${ }^{54}$ Untuk memberi pengajaran dalam bidang kerja gereja

52 Bestian Simangunsong, "Korupsi sebagai Musuh Bersama: Merekonstruksi Spiritualitas Anti Korupsi dalam Konteks Indonesia," BIA': Jurnal Teologi dan Pendidikan Kristen Kontekstual 1, no. 2 (2018): 217, https://doi.org/10.34307/b.v1i2.52.

53 Band. Daniel Nugraha Tanusaputra, "Kerohanian dan Pelayanan Seorang Hamba Tuhan," Veritas: Jurnal Teologi dan Pelayanan 14, no. 2 (2013): 256-259., https://doi.org/10.36421/veritas.v14i2.281 Tiga hal usulan Tanusaputra patut disandingkan untuk usulan Peneliti.

54 Pola pengajaran katekisasi out door, seperti yang dicontohkan GKI Kasih Perumnas Sorong, bisa menjadi referensi untuk gereja lain (lih. Natasya Virginia Leuwol, "Pendidikan Katekisasi Kepada Remaja di Jemaat Gki Kasih Perumnas Sorong," Journal of Dedication to Papua Community 1, no. 1 (2018): 40, https://doi.org/10.34124/269162.) 
mempersiapkan dunia kerja (pabrik, kantor atau wirausaha) yang baik dan tepat guna dijadikan tujuan kunjungan katekisasi untuk pola kerja kristiani yang benar.

\section{KESIMPULAN}

Allah adalah Allah yang bekerja serta memberi mandat kepada manusia untuk bekerja. Bekerja adalah hakikat dasar manusia. Menolak bekerja berarti mengingkari diri sebagai peta dan teladan Allah. Bekerja berarti menjaga seluruh ciptaan, memenuhi perhatian dan kepedulian Allah, tidak sebagai kutukan. Ketika bekerja, seseorang melakukannya sama seperti ketaatan kepada Kristus. Tujuan manusia bekerja adalah: memenuhi kebutuhan hidup, secara sosial bekerja adalah relasi bagi sesama, setiap orang saling memperlengkapi dan bekerjasama mencapai tujuan, untuk melayani sesama, sebagai sebuah kehormatan karena dipercaya melakukan tugas, memiliki kemampuan profesional, dapat berprestasi dan memiliki kinerja bermutu tinggi

\section{DAFTAR PUSTAKA}

Banks, Robert, dan R. Paul Stevens, ed. The Complete Book of Everyday Christianity. Revised. Singapore: Graceworks, 2011.

Benyamin, Yoel. Keselamatan dan Kehhidupan Kristen; Studi Eksegesa Terhadap Kitab Efesus. Luwuk: Pustaka Star's Lub, 2020.

Boky, Yonas. "Analisis Tingkat Kepuasan Mahasiswa Terhadap Pelayanan Akademik Sekolah Tinggi Theologia Jaffray Makassar." Jurnal Jaffray 14, no. 2 (2016): 269-90. https://doi.org/10.25278/jj71.v14i2.213.

Brien, Peter T O’. The Letter to the Ephesians. Grand Rapids: Eerdmans, 1999.

Cho, Bernardo. "Subverting Slavery: Philemon, Onesimus, and Paul' s Gospel of Reconciliation." Evangelical Quarterly 86, no. 2 (2014): 9-115. https://doi.org/0014-3367.

Clunie, Mary W. The Bible and Slavery: A Brief Examination of the Old and New Testaments on Servitude. London: Forgotten Books, 2018. 
Cohick, Lynn H. "Ephesians 6." Dalam Ephesians: A New Covenant Commentary, 1st ed., 143-61. Cambridge UK: The Lutterworth Press, 2020. https://doi.org/10.2307/j.ctt $1 \operatorname{cg} 4 \mathrm{~m} 17.11$.

Dachi, Otoriteit, dan Delipiter Lase. "Etos Kerja Pendeta BNKP." SUNDERMANN: Jurnal Ilmiah Teologi, Pendidikan, Sains, Humaniora dan Kebudayaan 13, no. 1 (2020): 48-64. https://doi.org/10.36588/sundermann.v13i1.34.

Ermindyawati, Lilis. "Konseling Kristen Terhadap Wanita Yang Mengalami Kecanduan Kerja." Evangelikal: Jurnal Teologi Injili dan Pembinaan Warga Jemaat 1 No.1 (2017): 67-74.

Ginzburg, Carlo. "Latitude, Slaves, and the Bible." Dalam Science without Laws, 243-63. Durham: Duke University Press, 2021. https://doi.org/10.2307/j.ctv1220m9h.14.

Grizzle, Trevor. Ephesians, A Pentecostal Commentary. Disunting oleh John Christopher Thomas. Ephesians. Leiden: Brill, 2019. https://doi.org/10.1163/9789004397224.

Gunadi, Paul, dan dkk., ed. Memaksimalkan Karier Anda: Kumpulan Artikel Tentang Menemukan dan Mengembangkan Karier. Bandung: PT. Visi Anugerah Indonesia, 2014.

Hamilton, Ian. Ephesians: The Lectio Continua Expository Commentary on the New Testamen. Disunting oleh Joel R Beeke dan Jon D Payne. Grand Rapids: Reformation Heritage Books, 2017.

Hamzah, Amir. Metode Penelitian Fenomenologi. Malang: Literasi Nusantara, 2020.

—. Metode Penelitian Kualitatif. Malang: Literasi Nusantara, 2019.

Harrill, J. Albert. "Ethnic Fluidity in Ephesians." New Testament Studies 60, no. 3 (2014): 379-402. https://doi.org/10.1017/S0028688514000046.

Hutahaean, Hasahatan. "Mengenal Ciri Tafsiran Ajaran Sesat." Didaskein 1, no. 1 (2013): 55-74. https://doi.org/ISSN 2338-2503.

- "Pengantar Memahami Surat Roma Dengan Baca Gali Alkitab." Cultivation 1, no. 2 (2017): 216-30.

Keller, Timothy, dan Katherine Learly Alsdorf. Apakah Pekerjaan Anda Bagian dari Pekerjaan Allah: Mengaitkan Karya Anda Dengan Karya Allah. Disunting oleh Sutrisna Harijanto. Surabaya: Perkantas Jawa Timur, 2014.

Kittel, Gerhard, dan Gerhard Friedrich, ed. Theological Dictionary of the New Testament. Grand Rapids: Wm. B. Eerdmans Publishing Co., 1997. 
Kurniadi, Trisno. "Penguasaan Diri Hamba Tuhan Dalam Pelayanan Kajian Eksegetikal 2 Timotius 4:1-8." Manna Rafflesia 3, no. 2 (2017): 131-56. https://doi.org/10.38091/man_raf.v3i2.72.

Leuwol, Natasya Virginia. "Pendidikan Katekisasi Kepada Remaja di Jemaat Gki Kasih Perumnas Sorong." Journal of Dedication to Papua Community 1, no. 1 (2018): 32-41. https://doi.org/10.34124/269162.

Lim, Heri. "Memahami Kisah Penciptaan Manusia Dan Alam Semesta: Sebuah Pendekatan LitererTerhadap Kejadian1-2." Amanat Agung 14, no. 2 (2018): 181-206. https://doi.org/10.47754/jaa.v14i2.355.

Lincoln, Andrew T. "Ephesians." Dalam The Cambridge Companion to St Paul (Cambridge Companions to Religion), disunting oleh James D. G Dunn, 133-40. Cambridge UK: Cambridge University Press, 2006. https://doi.org/10.1017/CCOL0521781558.010.

Manurung, Frans Setyadi. "Teologi Keramahan Allah: Sebuah Pembacaan Kristologi Lukas." Gema Teologika: Jurnal Teologi Kontekstual dan Filsafat Keilahian 3, no. 2 (2018): 185-206.

Mcgrath, Alister E. "The Lord is my light: on the discipleship of the mind The shaping of a Christian mind." Evangelical Quarterly 83, no. 2 (2011): 133-45. https://doi.org/0014-3367.

$\mathrm{Ng}$, Wirianto, Gundari Ginting, dan Lukgimin Aziz. "Hubungan Pemahaman Pelayanan Dan Panggilan Dengan Kesetiaan Pengerja Di Gereja." Manna $\begin{array}{lllll}\text { Rafflesia } & 7, & \text { no. } & 1 & \text { (2020): }\end{array}$ https://doi.org/10.38091/man_raf.v7i1.134.

Noor, Juliansyah. Metodologi Penelitian: Skripsi, Tesis, Disertasi, dan Karya Ilmiah. Jakarta: Kencana Prenada Media Group, 2011.

Parhalado Sekretaris Huria. "Buku Data Base Jemaat HKBP Tanjung Sari." Medan, 2018.

Priesteta, Astrid Cynthia. "Mengintegrasikan Pelayanan Sosial Melalui Pusat Kesejahteraan Sosial (Puskesos) Di Kelurahan Dago Kota Bandung." Pekerjaan Sosial 18, no. 1 (2019): 89-101. https://doi.org/10.31595/peksos.v18i1.158.

Richardson, Alan. The Biblical Doctrine of Work. London: SPCM Press, 1963.

Rimun, Robinson. "Latar Belakang Hidup Dan Pendidikan Rabinik Paulus Dalam Kaitannya Dengan Perjumpaannya Dengan Kristus." PASCA: Jurnal Teologi Dan Pendidikan Agama Kristen 15, no. 2 (2019): 1-8. https://doi.org/10.46494/psc.v15i2.60.

Roth, Ulrike. "Paul, Philemon, and Onesimus: A Christian design for mastery." Zeitschrift fur die Neutestamentliche Wissenschaft und die Kunde der 
Alteren Kirche 105, no. 1 (2014): 102-30. https://doi.org/10.1515/znw2014-0006.

Sairah Z, Abdul Rokhmat. "Etos Kerja Manusia Bugis-Makassar Sebagai Kritik Terhadap Konsep Kerja Dalam Budaya Kapitalisme Baru (Studi Filosofis Atas Persoalan Pengangguran di Indonesia)." Jurnal Filsafat 21, no. 1 (2011): 49-71. https://doi.org/10.22146/jf.4745.

Sanders, James A. "Jubilee in the Bible." Biblical Theology Bulletin 50, no. 1 (2020): 4-6. https://doi.org/10.1177/0146107919892838.

Seng, Cuan Lie. Calling at Work, Rahasia Bekerja dengan Totalitas. Bandung: PT.Visi Anugerah Indonesia, 2015.

Setiawan, David Eko. "Dampak Injil Bagi Transformasi Spiritual Dan Sosial." BIA': Jurnal Teologi dan Pendidikan Kristen Kontekstual 2, no. 1 (2019): 83-93. https://doi.org/10.34307/b.v2i1.78.

Simangunsong, Bestian. "Korupsi sebagai Musuh Bersama: Merekonstruksi Spiritualitas Anti Korupsi dalam Konteks Indonesia." BIA': Jurnal Teologi dan Pendidikan Kristen Kontekstual 1, no. 2 (2018): 204-19. https://doi.org/10.34307/b.v1i2.52.

Sinamo, Jansen dan Eben Ezer Siadari. Teologi Kerja Modern dan Etos Kerja Kristiani. Jakarta: Institut Darma Mahardika 2011, 2013.

Stevens, R.Paul. The Other Six Days: Vocation, Work and Ministry in Biblical Perspective. UK: Patermoster Publishing, 2000.

Stevens, R.Paul, dan Alvin Ung. Taking Your Soul to Work, Mengatasi Sembilan Dosa Maut di Tempat Kerja. Jakarta: Literatur Perkantas, 2014.

Sullivan-Dunbar, Sandra. Human Dependency and Christian Ethics. Human Dependency and Christian Ethics. London: Cambridge University Press, 2017. https://doi.org/10.1017/9781316717677.

Talan, Yesri Esau. Diselamatkan Oleh Anugerah: Sebuah Analisis Teologis Surat Efesus. Disunting oleh Made Nopen Supriadi. Bengkulu: Permata Rafflesia, 2021.

Tanusaputra, Daniel Nugraha. "Kerohanian dan Pelayanan Seorang Hamba Tuhan.” Veritas : Jurnal Teologi dan Pelayanan 14, no. 2 (2013): 253-76. https://doi.org/10.36421/veritas.v14i2.281.

Turner, Max. "Approaching 'personhood' in the New Testament, with special Reference to Ephesians." Evangelical Quarterly: An International Review of Bible and Theology 77, no. 3 (2021): 211-33. https://doi.org/10.1163/27725472-07703002. 
Uygur, Selçuk, Laura J. Spence, Ruth Simpson, dan Fahri Karakas. "Work Ethic, Religion and Moral Energy: the Case of Turkish SME Owner-Managers." International Journal of Human Resource Management 28, no. 8 (2017): 1212-35. https://doi.org/10.1080/09585192.2016.1166790.

Wahana, Paulus. "Mengusahakan Kebahagiaan Dalam Kegiatan Kerja." Jurnal Filsafat 27, no. 2 (2018): 243-63. https://doi.org/10.22146/jf.32803.

Wicaksana, Seta A, Rosi Nurika, dan Aisyah Pia Asrunputri. "Gambaran Etos Kerja Pada Karyawan Generasi Milenial di PT X." ISOQUANT : Jurnal Ekonomi, Manajemen dan Akuntansi 4, no. 2 (2020): 186-97. https://doi.org/10.24269/iso.v4i2.457.

Wright, Tom. Kisah Para Rasul Untuk Semua Orang I. Disunting oleh Nancy Poyoh. Surabaya: Literatur Perkantas Jawa Timur, 2011.

Zega, Sabaria. "Pentingnya Memahami Entrepreneurship Secara Biblikal bagi Hamba Tuhan." Kharismata: Jurnal Teologi Pantekosta 1, no. 2 (2019): 118-32. https://doi.org/10.47167/kharis.v1i2.16. 